\title{
TÜRKIYE'DE SPOR KULÜPLERININ ŞIRKETLEŞMEYE YÖNELIMLERININ DEĞERLENDIRILMESi
}

\author{
Sebahattin DEVECiOĞLU ${ }^{1} \quad$ Bilal ÇOBAN $^{2}$ \\ Yunus Emre KARAKAYA ${ }^{3}$ Özgür KARATAŞ ${ }^{4}$
}

Geliş Tarihi: 23.12.2011

Kabul Tarihi: 03.12.2012

\section{ÖZET}

Yeni ekonomik düzen her alanda olduğu gibi sporu ve kurumlarını etkilemiş, siyasal ve ekonomik sistemler içerisinde yer alan spor yeniden tanımlanmaya başlamıştır. Yüzyıllardır geleneksel yapılarını korumaya çalışan spor sistemleri, yeni ekonominin tanımlamış olduğu spor sektörünün avantajlarından yararlanmak ve rekabet edebilecek yapısal özeliklerini yeniden gözden geçirmek durumunda kalmışlardır.

Günümüzde spor kulüpleri gelişen ekonomiye ve profesyonel yönetim anlayışına sahip olmanın yanı sıra performanslarını artırmak ve başarıı olmak amacıyla birer işletme anlayışı içerisinde şirketleşme modellerini benimsemiş durumdadırlar. Türkiye'de spor kulüpleri bir taraftan vergi avantajlarından faydalanmak için dernek statüsünde faaliyetlerine devam ederken, diğer taraftan şirketleşerek kurumsallaşma, profesyonelleşme, ticari faaliyetlerde bulunma, markalaşabilme, gelir kaynakları yaratma gibi çabalara yönelmişlerdir.

Bu çalışmada, Türkiye'deki yeni yasal düzenlemeler ışığında, spor kulüplerinin yapısal özelliklerinin değişimi ile birlikte şirketleşme modellerinin ticari avantajlara dönüşümü betimsel olarak değerlendirilmiştir.

Anahtar Kelimeler: Spor Kulüpleri, Dernek, Şirketleşme, Şirketleşme Modelleri

\section{EVALUATION OF SPORTS CLUBS IN TURKEY ORIENTATION INCORPORATION}

\begin{abstract}
The new economic order has affected sports and its institutions as in every area and sport began to be redefined in political and economic systems. For centuries, sport systems which have been trying to protect their traditional structures had to take advantage of the sports industry defining by the new economy and had to reconsider structural properties that can compete.

Today, sports clubs have emerging economies as well as having professional management and to improve their performance in order to be successful have adopted a business model approach. Sports clubs in Turkey headed towards such efforts; on the one hand to take advantage of tax benefits, while continuing their activities association with the status, on the other hand the company becoming institutionalized, professionalisation, commercial activities, trying to be brand, creating sources of income.

In this study, in light of new legislation in Turkey, the change of the structure of sports clubs with business model transformation to the commercial advantages were evaluated descriptively.
\end{abstract}

Key Words: Sports Clubs, Association, Incorporation, Incorporation Models

\section{GIRIŞ̧ VE AMAÇ}

Günümüzde sporun değişen yüzüyle karşı karşıya kalan spor kulüpleri, değişim sürecine ayak uydurabilmek için değişmek ve yeniden yapılanmak zorunda kalmışlardır. Önceden amatör yöneticiler tarafından yönetilen spor kulüpleri, alanlarında uzman olan yöneticiler tarafından yönetilmeye başlamıştır. Bu uzman kadroların kulüpler tarafından istihdam edilmesi, spor kulüplerini profesyonel bir şekilde yönetilen birer işletme haline dönüştürmüştür (12). Sermaye piyasalarına yönelen kulüpler aynı zamanda endüstriyel gelişime uygun kurumsal bir yapıyı da oluşturma süreçlerini bu

Fırat Üniversitesi Beden Eğitimi ve Spor Yüksekokulu, Elazı̆̆

Fırat Üniversitesi Beden Eğitimi ve Spor Yüksekokulu, Elazığ

3 İl Milli Eğitim Müdürlüğü Şair Hayri İlköğretim Okulu, Elazığ

4 Fırat Üniversitesi Sağlık Bilimleri Enstitüsü, Elazığ 
şekilde başlatmışlardır. Kulüpler bir yandan sermaye piyasalarından fon temin ederlerken, diğer yandan kurumsallaşarak, profesyonelleşmeye başlamışlardır (22). Rekabetçi piyasa içinde kulüplerin pastadan maksimum payı alabilme mücadelesi, kulüpleri yeni gelir kaynakları yaratma yoluna itmiştir. Bu amaçla, kulüpler daha değişik, daha uzun vadeli ve daha düşük maliyetli fonları sağlayabilmek için sermaye piyasalarına açılmışlardır (13). Bundan dolayı sporun endüstriyel bir süreç içine girmesiyle birlikte, spor kulüplerinin hızla şirketleşmeye başladıkları görülmektedir. Aslında bu gelişme, futbolun geçirdiği yapısal değişimin de bir göstergesidir. Çünkü futbola ilişkin tüm öğelerin nitelik ve niceliksel değişim ve gelişimi, spor kulüplerini şirketleşmeye zorlamıştır (1).

Bu çalışmada, Avrupa Birliği sürecinde bulunan Türkiye'de yeni yasal düzenlemeler ışığında, spor kulüplerinin yapısal özelliklerinin değişimi ile birlikte şirketleşme modellerinin ticari avantajlara dönüşümü incelenmiş, spor kulüplerinin şirketleşme biçimleri ve modelleri örnekleri ile birlikte betimsel olarak açıklanmıştır.

\section{SPOR KULÜPLERININ YAPISAL ÖZELLIKLERI}

Spor kulüpleri belirli kurallara göre kurulan (yasalar, tüzükler, yönetmelikler, sözleşmeler vb.), üyelerinin her birinin yetki ve sorumlulukları belli olan (başkan, yönetim kurulu üyesi, denetçi, üye) gerek amatör gerekse profesyonel spor branşları ile topluma hizmet veren, her yaş grubunun spor yapabileceği tesis araç gereçlere sahip olan, diğer bir yönü ile de yüksek performans sporcuların yetiştirilmesini hedefleyen özel hukuk kuruluşlarıdır (17). Türkiye'de spor kulüplerine ilişkin yasal düzenlemeler, 5253 sayılı dernekler kanununun "Gençlik ve Spor Kulüpleri” başlıklı 14. maddesinde yer almaktadır. Buna göre kamu kurum ve kuruluşlarında, yükseköğretim kurumlarında ve özel kuruluşlarda, kendi mensupları tarafından, spor faaliyetlerini yönlendirmek ve boş zamanları değerlendirmek için bu kurum ve kuruluşlar bünyesinde dernekler kurulabilmektedir (12). Spor kulüplerinin tescil işlemleri 3289 sayılı Gençlik ve Spor Genel Müdürlügü̈nün Teşkilat ve Görevleri Hakkında Kanun'un 2 (d) maddesi uyarınca spor kulüpleri anılan Genel Müdürlük tarafından yapılmakla birlikte futbol branşında faaliyet gösteren kulüplerin lisans sistemleri işlemleri ise aynı kanunun 12. maddesi uyarınca Türkiye Futbol Federasyonu yönetim kurulu tarafından yapılmaktadır $(9,31)$.

Türkiye'de spor kulüpleri yapılanma şekilleri incelendiğinde dernek ve şirket olmak üzere iki farklı şekilde kuruldukları görülmektedir. Spor kulüplerinin bu yapılanma şekilleri aşağıda geniş bir şekilde açıklanmıştır.

\section{Dernek Şeklinde Olan Spor Kulüpleri}

Spor kulüpleri, 04.11.2004 tarihli ve 5253 sayılı Dernekler Kanunu ile 31.3.2005 tarihli ve 25772 sayılı Resmi Gazete'de yayımlanan Dernekler Yönetmeliğine göre fiil ehliyetine sahip gerçek veya tüzel kişiler tarafından kurulabilmektedir (6). Dernekler, kar amacı güden kurumlar olmadığından, Avrupa'da ve Türkiye'de olduğu gibi kulüpler ticari faaliyette bulunamamakta, bu anlamda sadece sportif etkinlikler gerçekleştirebilmektedirler. Türkiye'de spor kulüplerinin dernek kimliğinde faaliyetlerini sürdürmelerinin en büyük nedeni, ticari faaliyette bulunmama dezavantajına karşılık, önemli vergisel avantajlardan faydalanıyor olmalarıdır. Bu avantajlar sırasıyla (27); Katma Değer Vergisi (KDV Kanunu, m. 17), Damga Vergisi (Damga Vergisi Kanunu, m. 9), Emlak Vergisi (Emlak Vergisi Kanunu, m. 4), Gümrük Vergisi (Gümrük Kanunu, m. 167) ve harç istisnası, Veraset ve İntikal Vergisi Muafiyeti, (Veraset ve İntikal Vergisi Kanunu, m. 3) ve Bağış ve yardımların gelirlerden indirilebilme (Kurumlar Vergisi Kanunu, m. 10) imkânıdır. Türkiye'de dernek şeklinde olan spor kulüpleri, "Spor Kulübü (Dernekler Kanunu Madde: 1)", "Gençlik ve Spor Kulübü (Dernekler Kanunu Madde: 57/1) " ve "Kurum Kulübü” şeklinde örgütlenmişlerdir.

\section{Ticaret Şirketi Şeklinde Olan Spor Kulüpleri}

Günümüzde spor kulüpleri, kendini gösteren ekonomik rekabet, endüstrileşen futbol, spor kulüplerinin maddi kazanç uğruna gerçek amacı dışına çıkması, spor kulüplerinin taraftarları tribünlere getirebilmek için çeşitli faaliyetlere yönelmesi gibi nedenlerle şirketleşmeye yönelmişlerdir (26). 1990'lı yıllardan itibaren hızla yayılan dijital yayıncılık sisteminin etkisiyle seyircinin hızlı bir şekilde artması, dernek statüsü ile bu bütçeleri yönetemez hale geldikleri görülmektedir (27). Yine şirketleşen spor kulüpleri futbol endüstrisinde, sadece sportif faaliyetler alanında değil, bir takım ticari faaliyetler alanında yaratılan gelir kaynaklarından da pay almayı amaçlamışlar ve bu tür ticari faaliyetler için ayrı tüzel kişilikler kurma yolunu seçmişlerdir (1). Yukarıda da belirtildiği üzere spor kulüpleri esas olarak aşağıdaki sebeplerden dolayı şirketleşme yoluna gitmişlerdir (27).

- Büyük bütçelerin dernek olarak yönetiminin zorluğu,

- Kurumsallaşma ve profesyonelleşme,

- Halka arz,

- Dernek konumunda iken yapılamayan ticari faaliyetlerde bulunabilmek,

- Bağıı oldukları spor kulüplerine direkt olarak fon kaynağı sağlayabilmek,

- UEFA'nın 2004/2005 sezonundan itibaren lisans hakkı için zorunlu kıldığı kriterlere uyum açısından kurumsal yönetim ilkelerini uygulayabilmek,

- Uluslararası markalaşabilmek,

- Kredi temini kolaylığı yaratabilmek, 
- Büyüyen rekabet ortamında büyük ölçeklerde artan maliyetleri karşılayabilmek için yeterli kaynaklara ulaşabilmek ve vergi avantajlarından faydalanabilmektedir.

Spor kulüplerinin şirketleşmesinde taraftar gücü, sportif başarı ve deneyim, gayrimenkul ve altyapı varlığı, kamuoyundaki itibar, ulusal ve uluslar arası ölçekteki hayran potansiyeli artı değerler olarak görülmektedir. Aynı kapsam içerisinde var olan dezavantajlar ise başarıların ticari getiriye dönüşmemesi, mali ve idari yönetimde organizasyon eksiklikleri, planlama ve strateji yoksunluğu, geleceği ipotek altına alan ölçüsüz borçlanmalar, yönetimde kalite erozyonu, bağımsız denetim ve saydam bütçe eksikliği olarak görülebilir. Bugün için dünyada başarılı spor kulüpleri, iyi yönetilen spor kulüpleri şirketleri yeni ekonominin gereklerine uyarak medya, telekominikasyon ve internet alanında sponsorlar bularak yeni yatırımlara yönelmektedirler (4).

Spor kulüplerinin şirketleşmesi konusu ise ilk olarak 28.05.1986 tarih ve 3289 sayılı Gençlik ve Spor Genel Müdürlüğü'nün Teşkilat Görevleri Hakkındaki Kanunda (Madde No: 24) kanun, spor kulüplerinin profesyonel takımları Türk Ticaret Kanunu hükmüne göre kuracakları veya kurulmuş olan şirketlere devredebilmelerini öngörmektedir (32). Türkiye Futbol Federasyonu'nun çıkardığı Profesyonel Futbol ve Transfer Talimatı'nın 14. maddesinde yapılmıştır. Söz konusu talimat maddesinde kulüplerin, futbol faaliyetlerini, bir ticari şirket haline getirebilmek için Türk Ticaret Kanunu'na göre şirket kurabilecekleri veya futbol şubelerini kurulmuş olan şirketlere devredebilecekleri hükme bağlanmıştır. Ayrıca 5520 sayılı Kurumlar Vergisi Kanunu' nun (26205 sayılı ve 21.06.2006 tarihli Resmi Gazete) muafiyetleri düzenleyen 4. maddesi j bendinde yer alan Gençlik ve Spor Genel Müdürlüğü ile özerk spor federasyonlarına tescil edilmiş spor kulüplerinin idman ve spor faaliyetlerinde bulunan iktisadi işletmeleri ile sadece idman ve spor faaliyetlerinde bulunan anonim şirketler" hükmü çerçevesinde, futbol kulüplerinin şirketleşmesi durumunda, aynen dernek çatısı altında faaliyet gösterdiklerinde olduğu gibi kurumlar vergisinden muaf olmaları sağlanmıştır. Şirketleşen futbol kulüplerinin söz konusu muafiyetten yararlanabilmeleri için sadece idman ve spor faaliyetinde bulunmaları gerektiği belirtilmiştir. Yine 5520 sayılı Kurumlar Vergisi Kanunu uyarınca yayımlanan 1 seri nolu Kurumlar Vergisi Kanunu Genel Tebliği ile söz konusu şirketlerin elde ettikleri transfer ve bonservis gelirleri, saha reklam gelirleri, maç bileti satışları, sporcuların formalarına aldıkları reklamlar, maç yayın hakkının satılması faaliyetleri Türkiye'de sporun gelişimi ve kurumsallaşması amacıyla vergi kapsamı dışında bırakılmıştır. Buna paralel olarak kulüplerin hisselerinin halka arzını teşvik etmek için 5520 sayılı Kurumlar Vergisi Kanunu'nun 5 (ç) maddesi uyarınca anonim şirketlerin kuruluşlarında veya sermayelerini artırdıkları sırada çıkardıkları payların bedelinin itibari değeri aşan kısmı bilinen adıyla emisyon primleri kurumlar vergisinden istisna edilmiştir (9). Sermaye Piyasası Kurulu da, 7 Şubat 2002 tarih ve 9/181 sayılı kararıyla, halka açılan spor kulüplerinin "faaliyetlerine, aktif yapılarına, pasif yapılarına ve gelir yapılarına ilişkin, futbolcu transferlerinin açıklanmasına ilişkin kriterler ile futbolcu/teknik yönetime, gelir kayıplarına veya sözleşme fesihlerine / imzalanmasına ilişkin açıklamaları kapsayan özel durum açıklamalarına, diğer açıklamalar ile futbolcuların bonservis bedellerinin mali tablolara yansıtılmasına" ilişkin bir ayrıntılı şekilde belirlenmiş kriterlere yer vermektedir (10). Sanayi ve Ticaret Bakanlığı, kulüp tüzüklerin müsait olması kaydıyla sadece spor kulüplerine mahsus olmak üzere derneklerin ticaret şirketi kurmalarına izin vermektedir. Spor kulüpleri, spor kulüpleri federasyonları ve konfederasyon tüzüklerde yazılı amacı gerçekleştirmek için ticari şirket kurabilmektedir. İktisadi işletmelerini, tüzel kişilere ve şirketlere kiraya verebilecekleri gibi bir sermaye şirketine de devredebilirler. "Sermaye şirketlerinde kulüplerin payları \% 51 'in altında olamaz ve bu paylar üçüncü kişilere devredilemez ve buna ilişkin hüküm tüzüklerde yer alır” şeklinde belirtilmektedir. Spor kulüplerinin profesyonel futbol şubelerinin şirketleşmesi ile ilgili ticari bir yapıya kavuşacak olan spor kulüpleri, kulüplere bağış olarak verilecek paraların büyüklüğü ölçüsünde kulüp başkanı ve kulüp yönetici olan ve bazı durumlarda futbol kulübünün unvanını ve potansiyelini kendi çıkarları için kullanabilen, sorumlulukları dernekler kanunu çerçevesinde sınırlı olan kişilerce değil, işini iyi bilen profesyonel yöneticilerle yönetilmelidir. Bu şekilde kurulacak şirketler, dernek şeklinde örgütlenmiş bulunan ve bu nedenle de yürürlükte yasal mevzuat gereğince futbol kulüplerinin yapmayacağı birçok konuda faaliyet gösterebilecek ve gelir kaynaklarını önemli ölçüde artırabilecektir (21).

\section{SPOR KULÜPLERINDE ŞIRKETLEŞME MODELLERi}

Küreselleşen dünyada, yeni ekonomik düzen ve ticarileşme yapılanmaları spor kulüpleri şirketleşme çalışmalarına itmiştir. Bu yapılanmalar, bir çok şirketleşme modellerini ortaya çıkarmıştır (Şekil 1). Klasik dönemden günümüze dünyada beş şirketleşme biçiminden söz etmek mümkündür.

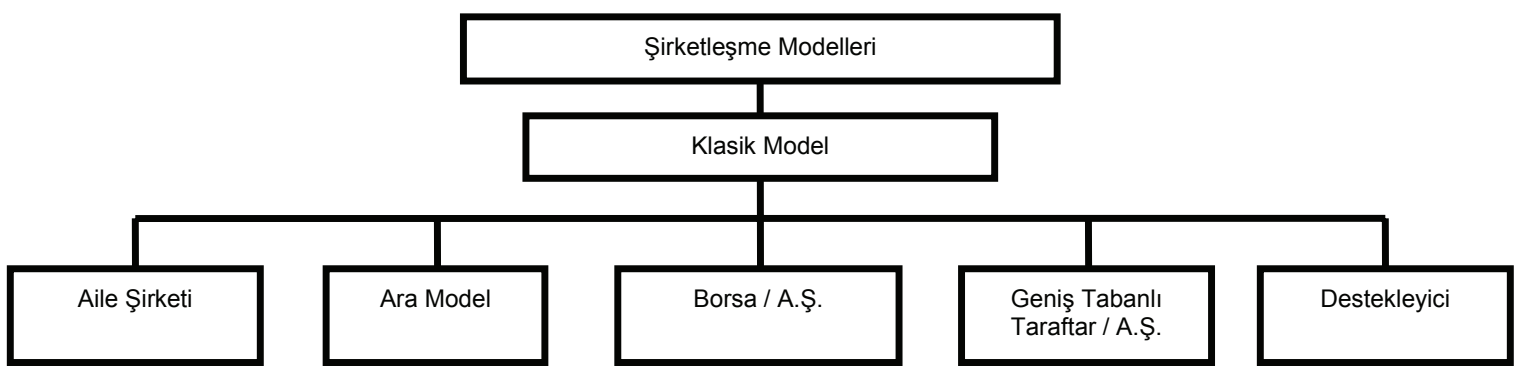

Şekil 1. Spor Kulüplerinin Şirketleşme Modelleri 
SPORMETRE Beden Eğitimi ve Spor Bilimleri Dergisi 2012, Cilt: X, Sayı:2

Spor kulüplerinin yapılanması ilk olarak "Klasik Model” ile başlamıştır. Yukarıda da belirtildiği üzere spor kulübü üyelerinden oluşan genel kurul ve buraya aday olan yönetimler vardır. Üyeler spor kulüplerinin finansal ortağı olmadıklarından ticari bir bağlantıları da yoktur. Bu modelde ana hedef hep sportif başarı olduğundan kulübün başarısı yönetiminin şahsi kaynaklarına ve idari becerisine bağlıdır. Örneğin, Kayserispor, Bursaspor, Ankaragücü, Konyaspor, Gençlerbirliği, Köln, Bochum gibi spor kulüpleri bu model ile yönetilmektedir. Dünyada ve Türkiye'de uygulanan şirketleşme modelleri incelendiğinde ise aşağıda açıklanan modeller olduğu görülmektedir. "Aile Şirketi;" tek kişinin veya belli bir aileye bağlıdır. Bu model çok tartışılmakla beraber İngiltere'de çok yaygındır. Bu modelin tek avantajı, kulübü kendi işi olarak gören bir hissedarın olmasıdır. Örneğin Chelsea, AC Milan, Liverpool, Fulham gibi spor kulüpleri bu modelle yönetilmektedir. Ara Model; klasik modelin devamı gibidir. Burada kulübün bir kısmı, örneğin gelirleri halka açılır. Örneğin; Galatasaray, Fenerbahçe, Trabzonspor, Borussia Dortmund, Bayer Leverkusen gibi spor kulüpleri bu model ile yönetilmektedir $(34,30)$.

Yukarıda açıklanan ve şirketleşmenin nedenlerinden biri olan "halka açılma (halka arz)", kulüplerin şirketleşmesinin en büyük nedenlerinden biri olarak kabul edilmektedir. Halka arz edilen kulüpler, hem uzun vadeli fonlanma imkanı bulmuşlar, hem de futbol rekabet piyasasında üstünlük sağlayabilme yoluna girmişlerdir (27). Ayrıca spor kulüplerinin halka arz ve piyasadaki hisse senetlerinin işlem görmesinden sağladığı avantajları, kulübün tanıtımı, kurumsallaşması, finansman sağlama gibi avantajlar sağlamaktadır. Spor kulüplerinin halka açılması iki yolla gerçekleşmektedir. Birincisi, mevcut şirketin hisse senetlerini veya sermaye artırım yoluyla arttırılan sermayeyi temsil eden hisse senetlerini halka arzı, ikincisi ise bir kısım payların kurucular tarafından taahhüt altına alınması ve geri kalan kısmın halka satışı ile olabilmektedir (21). Halka Açık Sportif A.Ş.'ler kurulurken, kulüpler markalarıyla ilgili ticari haklarını lisans hakkı kiralama sözleşmesi ile şirkete devretmektedirler. Diğer taraftan profesyonel futbol takımı şirkete kira sözleşmesi ile kiralanmaktadır. Kulübün üçüncü kişilerle yaptığı gelir nitelikli sözleşmeler de (sponsorluk, yayın geliri vb.) temlik sözleşmesi ile halka açık şirkete devredilmektedir (6). Yine spor kulüplerinin halka arzının yararlarını; spor kulübünün şirketine fon sağlama, spor kulübünün profesyonelleşmesi, tanınması, kurumsallaşması ve spor kulübü şirket hisselerinin pazardaki değerinin tespit edilmesi şeklinde belirtmek mümkündür.

Üçüncü şirketleşme modeli olan "Borsa/Anonim Şirket (A.Ş.)", ise spor kulüpleri normal bir şirket gibi borsaya açılır veya anonim şirket olur. Finansal olarak çıkış ve inişler yaşasa da futbolda pek çok anonim şirket vardır. Örneğin Beşiktaş, Juventus, Arsenal, Lazio, Ajax gibi spor kulüpleri bu model ile yönetilmektedir. "Geniş Tabanlı Taraftar / Anonim Şirket (A.Ş.);" klasik modele yakın bir modeldir. Ancak bu modelde genel kurul katılımcı sayısı çok olduğundan rasyonel kararlar alınıp, kulüp şirket gibi yönetilmektedir. Bu model genelde İspanya liglerinde kabul görmektedir. Örneğin Real Madrid, Barcelona, Atletic Bilbao gibi spor kulüpleri bu model ile yönetilmektedir. Şirketleşme modellerinde sonuncusu olan "Destekleyici" model ise spor kulüplerini kar odaklı sosyal kulüp haline getirmeye çalışan taraftar gruplarının kulübe ortak oldukları ve İngiltere'de 2000 yılında başlayan hükümet destekli bir modeldir $(34,23,30)$.

\section{AVRUPA'DA VE TÜRKIYE'DE SPOR KULÜPLERININ ŞIRKETLEŞMESI VE TICARI UYGULAMALARI}

Avrupa'da spor kulüpleri incelendiğinde, şirketleşmenin istenilen noktadan uzakta olduğu görülmektedir. Avrupa Futbol Birliği (UEFA)' nin mali kriterleri bir bakıma futbolun profesyonel yönetiminde şirketleşmeyi zımni anlamda destekliyor ve yönlendiriyorsa da hala Avrupa'da çoğu ülkede kulüplerin Türkiye'de olduğu gibi dernek statüsünde sportif etkinliklerini sürdürdükleri görülmektedir (3). Avrupa'da bazı sportif faaliyet gösteren spor kulüpleri incelendiğinde, profesyonel futbolda şirketleşme ve ticari gelir elde etmede İngiltere'deki liglerin ve kulüplerinin diğer liglerden önde olduğu görülmektedir (7). Almanya'da yer alan spor kulüplerinin çoğu, faaliyetlerine halen dernek statüsünde devam etmekte ve sportif faaliyetlerini dernek olarak devam ettirirken, futbol endüstrisinde giderek artan ürün satışından gelir sağlayabilmek için ana kulübe bağlı ayrı ticari tüzel kişilikler kurmayı tercih etmişlerdir. Kurulan bu şirketler, ürün satışlarından dolayı kısa zamanda yüksek bütçelere sahip olmuştur (1). İspanya'da spor kulüplerin hepsi halen faaliyetlerini dernek statüsünde devam ettirdikleri görülmektedir. Bu konumda olması, milliyetçi kültür ve geleneksel yapının korunması olarak gösterilmektedir (27). Fransa'da oynayan spor kulüplerinin büyük bir kısmı şirketleşmiştir. Rekabetin en yüksek olduğu liglerin başında gelen bu ligin, genellikle kar amacı gütmeyen şirketsel bir yapılanma içinde olduğu görülmektedir. Ayrıca Fransa'da mücadele eden spor kulüplerinin bazılarının ise özel sektör şirketleri tarafından desteklendiği görülmektedir (33). İtalya'da toplam gelirleri bakımından Avrupa'da beş büyük lig arasında \% 11'lik payı ile ikinci sırada yer almaktadır. Bu ligde faaliyet gösteren spor kulüpleri halen sadece dernek konumunda olan kulüpler olduğu gibi, aralarında şirketleşenleri de vardır (1). İtalyan kulüplerinin çoğu şirket olarak faaliyette bulunsalar da operasyonel anlamda kendilerinden beklenen mali ve operatif performansa ulaşamadıkları görülmektedir (8). Ayrıca İngiltere dışında en fazla futbol spor kulübünün borsada işlem gördüğü ülke olarak Danimarka karşımıza çıkmaktadır. Danimarka'da bir çok spor kulübünün borsada işlem gördüğü görülmektedir (3). Yine Portekiz ve İskoçya'da bazı spor kulüplerinin borsada işlem gördüğü Hollanda'da ise spor kulüpleri, üyelerin mülkiyetinde bulunmakta ve kulüpler istisnalar dışında yüksek bağış ve yardımlarla faaliyetlerini devam ettirdiği ve spor kulüplerinin yapısı gereği şirketleşmede arzu edilen noktaya henüz ulaşmadığı görülmektedir $(3,10)$.

Türkiye'de şirketleşme yoluna giden spor kulüpleri incelendiğinde ise Malatyaspor, Türkiye'de futbol kulüplerinin şirketleşmesinde ortaya çıkan ilk spor kulübü olduğu görülmektedir. Malatyaspor, futbol şubesini, kurduğu Malatyaspor A.Ş'ye devretmiştir. Ancak Malatya Spor A.Ş. 1. ligden düşmesinin ardından tasfiye edilmiştir. İstanbulspor'un futbol 
şubesi İstanbulspor Faaliyetleri ve Ticaret A.Ş.'ye devredilmiştir. Çanakkale Dardanelspor A.Ş. 1996-1997 sezonunda şirketleşerek Dardanel Spor Faaliyetleri Anonim Şirketi adını almıştır. Karşıyaka Spor Kulübü A.Ş., 1998 yılında Holding'e devir olarak anonim şirkete dönüştürülmüştür. Holding ile bünyesindeki bazı şirketlerin ortak olduğu şirkete Karşıyaka Spor Hizmetleri ve Ticaret A.Ş. adı verilmiştir. Adanaspor A.Ş., 1998 yılında şirketleşerek Adanaspor Spor Faaliyetleri Anonim Şirketi adını almış (11) ve 2005 yılında ekonomik sıkıntılardan dolayı iflas etmiştir. Ancak 2004 yılında Tasarruf Mevduatı Sigorta Fonununa devredilmesiyle kulüp 2. lige düşerek tasfiye edilmiştir. Vanspor şirketleşerek şirket konuma geçerek sınır ticaretinden ve işlettiği lokantalardan elde ettiği gelirleri kulübe aktarmıştır. Ancak valilik şirketi özelleştirme yoluna gitmiştir. Göztepe Spor Kulübü'nün futbol şubesi 1998 yılında şirketleşerek Göztepe Spor Hizmetleri ve Ticaret A.Ş. adını almıştır. Futbol faaliyetlerini Anonim Şirket bünyesinde sürdürmeye başladıktan sonra yapay bir yükseliş yaşayan kulüp iflas ederek Tasarruf Mevduatı Sigorta Fonuna devredilmiştir (19).

Galatasaray spor kulübü medya, reklam ve pazarlama aktivitelerinin futbol takımının yönetiminden ayrılması amacıyla 2000 yılında, futbolla ilgili tüm yayın ve reklam haklarını Galatasaray Sportif'e devretmiştir. Galatasaray Sportif, dünyanın en büyük spor pazarlama şirketlerinden biri ile anlaşarak reklam, imaj, pazarlama ve bazı medya haklarının yönetilmesi görevini 30 Haziran 2005 yılına kadar bu şirkete devretmiştir (20). 2000 yılında Galatasaray ile şirket arasında imzalanan bir diğer sözleşme ise Futbol Takımı Kira Sözleşmesi'dir. Bu sözleşmeye göre şirket, Galatasaray'ın profesyonel futbol takımını 30 yıl süre ile kiralamıştır. Kira Sözleşmesi'yle devredilen haklara rağmen şirket, profesyonel futbol takımının ve ilgili spor aktivitelerinin yönetiminden sorumlu değildir. 2004 tarihinde imzalanan devir sözleşmesi uyarınca Galatasaray, Futbol Takımı Kira Sözleşmelerinden doğan hak ve yükümlülüklerini Futbol A.Ş.'ye devretmiştir (27). Galatasaray kulübünün tüm gelirleri Galatasaray Sportif A.Ş.'de toplanmaktadır. Şirketin futbolcu lisansları ve harcamaları ise Galatasaray Futbol Yatırımları A.Ş.'de bulunmaktadır. 2006 yılında alınan bir kararla Galatasaray Sportif A.Ş. ile Galatasaray Spor ve Futbol İşletmeleri şirketleri birleşme kararı almışlardır. Ayrıca Galatasaray hisselerinin \% 68 'i yabancı kurumsal yatırımcıların elinde bulunmaktadır. Şirketin gelirleri çeşitli kuruluşlarla yapılan orta vadeli anlaşmalarla sağlanmakta, giderleri ise personel ve genel yönetim giderleri, kulübe ödenen kira ücretleri ile diğer yönetim komisyonundan oluşmaktadır (14). Galatasaray Spor Kulübü kurmuş oldukları Galatasaray ve Stad İşletmeciliği Ticaret A.Ş. aracılığı ile Ali Sami Yen Stadının intifa hakkını satın alarak yerine yeni her türlü konforun bulunduğu daha modern bir stad inşa etmeyi planlamıştır (15).

Beşiktaş Spor Kulübü, futbolla ilgili tüm gelir ve giderleri ile tüm aktif ve pasif değerlerini Beşiktaş Futbol Yatırımları A.Ş. adlı şirkete devretmiştir (33). Şirket, kurumlar vergisi muafiyetinden yararlanabilmek için değişik alanlarda ticari faaliyetlerini sürdürmek amacıyla \% 99,9'una sahip olduğu çeşitli bağlı ortaklıklar kurmuştur. 2001 yılında Beşiktaş Sportif Ürünler A.Ş. kurulmuştur. Bu şirket, Beşiktaş marka, logo ve amblemli ürünlerin üretim ve pazarlanması faaliyetini yürütmektedir (6). Ayrıca, faaliyet konusu yurt içi ve yurt dışı turlar organize etmek, bilet satışı yapmak ve vize işlemleri faaliyetlerinde bulunmaktan ibaret olan bir diğer bağlı ortaklık 2003 yılında kurulan Beşiktaş Turizm İşletmeleri ve Yatırımları Sanayi ve Ticaret A.Ş.'dir. Şirket'in aynı ortaklık payına sahip olduğu bir diğer anonim şirket ise Beşiktaş Sigorta Aracılık Hizmetleri A.Ş. 2003 yılında kurulmuş olup, sigorta aracılık faaliyetlerinde bulunmaktadır (27). Beşiktaş Avrupa'daki şirketler gibi gelir ve giderlerini aynı çatı altında toplamakta Beşiktaş'ın Sportif A.Ş. olarak şirketin yapılanması temelde Manchester Unıted Spor Kulübü modeli esas alınmıştır. Bu modelde sportif başarı tek başına önemli değildir. Bu modelde ciddi gelir getirecek işletme ve rant gelirleri önemli yer tutmakta şirketin en önemli dezavantajı ise yapılacak oyuncu ve teknik adam transferinin gider olarak, şirket muhasebesine yansıtılıyor olması bir yandan karlılığı olumsuz etkilemektedir (5).

Fenerbahçe Spor Kulübünde şirketleşme, 1998 yılında 1907 Fenerbahçe Sportif Hizmetler Sanayi ve Ticaret A.Ş. unvanıyla sporun bütün dallarıyla ilgili ticari ve sınai faaliyetlerde ve yatırımlarda bulunmak üzere kurulmuştur. 2000 yılında şirketin unvanı bugünkü halini almıştır. Fenerbahçe Sportif'in kurumlar vergisinden muaf bir yapıya kavuşması için 2002 yılında Fenerbahçe Sportif'in ticari faaliyetleri Fenerbahçe Spor Ürünleri Sanayi ve Ticaret A.Ş.'ye devredilmiştir. Bu şirket, Fenerbahçe taraftar ürünleri ve diğer her türlü spor malzeme ve spor giysileri, reklam ve taraftar ürünlerinin satış ve pazarlamasını yapmak üzere Fenerium mağazalarını işletmektedir. Fenerbahçe markalarının yasal sahibi olan Fenerbahçe Spor Kulübü, bu markalara ilişkin lisans haklarını Fenerbahçe Sportif'e 2004 yılında imzalanan lisans kiralama sözleşmesiyle 30 yılığına kiralamıştır (20). Buna göre 2004 yılında yapılan lisans ve temlik sözleşmeleri ile gelirler şirkete devredilmiş, takım ile ilgili giderler ise Fenerbahçe bünyesinde bırakılmıştır (27).

Trabzonspor kulübünde ise şirketleşme, Trabzonspor Sportif Yatırım ve Ticaret A.Ş. 1994 yılında Trabzon'da Trabzonspor Gıda Yatırım Ticaret Anonim Şirketi unvanıyla Trabzonspor Kulübü Derneği kuruluşu olan Trabzonspor Futbol İşletmeciliği Ticaret A.Ş. \% 100 iştiraki olarak kurulmuştur (28). Trabzonspor Kulübü'nün doğrudan \% 99.9'una iştirak ettiği Trabzonspor Futbol İşletmeciliği Ticaret A.Ş., 2004 yılında Trabzonspor Kulübü ile imzaladığı sözleşme Trabzonspor kulübünün profesyonel futbol şubesini tüm aktif ve pasifi ile birlikte süresiz olarak devralmıştır (33). Trabzonspor markalarının tek, meşru, yasal ve süresiz sahibi olan Futbol A.Ş. ile şirket arasında imzalanan Lisans Kiralama Sözleşmesi ve Profesyonel Futbol Takımı Kiralama Sözleşmesi uyarınca, Trabzonspor Sportif A.Ş., 30 yıl süreyle, Trabzonspor marka, pazarlama ve lisans haklarına, profesyonel futbol takımının uluslararası müsabakalardan elde ettiği performans ve pazarlama gelirlerinin bir kısmına ve Futbol A.Ş. tarafından elde edilecek stadyum hasılatlarının büyük bir kısmına sahip olacaktır (20). 
Tablo 1. Spor Kulüplerinin Şirketleşme Sürecindeki Gelirlerinin Karşılaştırılması

\begin{tabular}{|c|c|c|c|c|}
\hline $\begin{array}{l}\text { Spor A.Ş’lerin } \\
\text { Gelirleri }\end{array}$ & GS Sportif & BJK Sportif & FB Sportif & TS Sportif \\
\hline Yayın Hakkı & - & + & + & + \\
\hline Sponsorluk & + & + & + & + \\
\hline Reklam & + & + & + & + \\
\hline $\begin{array}{l}\text { Lisans ve İsim } \\
\text { Hakkı }\end{array}$ & + & $\begin{array}{c}\text { \% } 100 \text { iştiraki } \\
\text { Beşiktaş Sportif } \\
\text { Ürünler üzerinden } \\
\text { temettü }\end{array}$ & + & $\begin{array}{c}300.000 \text { Dolara ek olarak yıllık } \\
\text { ticari ürün satışlarının } 1 \mathrm{mn} \\
\text { doları aşması durumunda, } \\
\text { satışlardan } \% 10 \text { pay }\end{array}$ \\
\hline TV Kanalı & - & - & $\begin{array}{l}\text { FBTV'nin vergi öncesi } \\
\text { karının \% 50'si }\end{array}$ & - \\
\hline Maç Hasılatı & - & + & Yıllık $8.5 \mathrm{mn}$ dolar & Net satış hasılatının \% 80'i \\
\hline Bahis & - & + & + & + \\
\hline Ticaret Merkezi & - & - & $\begin{array}{c}\text { Devreye alındığında } \\
\text { kulübün elde edeceği } \\
\text { gelirler Sportif'e aktarılacak }\end{array}$ & - \\
\hline $\begin{array}{l}\text { Champions } \\
\text { League } \\
\text { Performans }\end{array}$ & $\begin{array}{l}\text { Başlangıç ve 1. Grup maç } \\
\text { primleri üzerinden } \% 60 \text {, } \\
\text { çeyrek, yarı final, final } \\
\text { performans primleirnden net } \\
\text { gelirin } \% 50 \text { 'si }\end{array}$ & + & Brüt gelirlerin \% 20'si & Brüt gelirlerin \% 20'si \\
\hline $\begin{array}{l}\text { UEFA Kupası } \\
\text { Yayın Havuzu }\end{array}$ & + & + & + & + \\
\hline $\begin{array}{l}\text { Transfer ve } \\
\text { Bonserviz }\end{array}$ & - & + & - & - \\
\hline
\end{tabular}

Tablo 1'de Türkiye'de dört profesyonel spor kulübünün şirketleşme sürecindeki gelirlerin karşılaştırılması verilmiştir (24). Burada Spor A.Ş.'Jerin gelirlerinin; yayın hakkı, sponsorluk, reklam, lisans ve isim hakkı, TV kanalı, maç hasılatı, bahis, ticaret merkezi, champions league performans, UEFA kupası yayın havuzu, transfer ve bonservislerden oluştuğu görülmektedir.

Tablo 2. Spor Kulüplerinin Şirketleşme Sürecindeki Giderlerinin Karşılaştırılması

\begin{tabular}{|c|c|c|c|c|}
\hline $\begin{array}{l}\text { Spor A.Ş’lerin } \\
\text { Gelirleri }\end{array}$ & GS Sportif & BJK Sportif & FB Sportif & TS Sportif \\
\hline Genel Yönetim & + & + & + & + \\
\hline $\begin{array}{l}\text { Antrenör- } \\
\text { Futbolcu }\end{array}$ & - & + & - & - \\
\hline Bonservis & - & + & - & - \\
\hline Transfer & - & + & - & - \\
\hline Kamp ve Tesis & - & + & - & - \\
\hline $\begin{array}{l}\text { Pazarlama } \\
\text { Şirketi }\end{array}$ & + & + & - & - \\
\hline Stadyum & - & $\begin{array}{c}\text { Kullanma ve } \\
\text { işletme hakkı } \\
\text { bedeli olarak } 2003 \\
\text { Aralık'da } 11,5 \mathrm{mn} \\
\text { dolar ödenmiş }\end{array}$ & $\begin{array}{l}2004 / 2005 \text { sezonundan } \\
\text { itibaren yıllık } 500.000 \text { dolar }\end{array}$ & - \\
\hline Lisans Bedeli & $\begin{array}{l}2005 \text { Haziran'dan itibaren } \\
\text { yıllık gelirlerin KDV hariç brüt } \\
\% 1 \text { 1'i (min. } 200.000 \text { dolar) }\end{array}$ & $\begin{array}{l}2003 \text { Aralık'da } \\
\text { BJK'dan } 18 \mathrm{mn} \\
\text { dolara satın } \\
\text { alınmış }\end{array}$ & - & - \\
\hline $\begin{array}{l}\text { Futbol Takımı } \\
\text { Kirası }\end{array}$ & $\begin{array}{l}\text { Kulübe Şampiyonlar Ligi } \\
\text { başlangıç ve 1. tur maç } \\
\text { primleri üzerinden } \% 30+ \\
2005 / 2006 \text { ezonundan } \\
\text { itibaren gelirlerin } \% 1.5 \text { 'u } \\
\text { (min. } 300.000 \text { dolar) }\end{array}$ & - & $\begin{array}{l}\text { Kulübe 2004/05 } \\
\text { sezonundan itibaren } \\
\text { gelirlerin \% 2'si (min } \\
500.000 \text { dolar) }\end{array}$ & $\begin{array}{l}\text { Kulübe } 2004 / 2005 \text { sezonundan } \\
\text { itibaren bir önceki sezon brüt } \\
\text { toplam gelirlerin } \% 1^{\prime} i\end{array}$ \\
\hline
\end{tabular}

Tablo 2'de Türkiye'de dört profesyonel spor kulübünün şirketleşme sürecindeki giderlerinin karşılaştırılması verilmiştir (24). Burada Spor A.Ş.'lerin giderlerinin genel yönetim, antrenör-futbolcu, bonservis, transfer, kamp ve tesis, pazarlama şirketi, stadyum, lisans bedeli ve futbol takımı kirasından oluştuğu görülmektedir. 
DEVECIOĞLU, S., ÇOBAN, B., KARAKAYA, Y.E., KARATAŞ, Ö.,"Türkiye'de Spor Kulüplerinin Şirketleşmeye Yönelimlerinin Değerlendirilmesi”

\section{SONUÇ}

Birçok ülkede olduğu gibi Türkiye'de de spor kulüpleri dernek statüsünde kurulmuş olup birçok vergiden muaf tutulmaktadırlar. Bu avantajı sürdürebilmek için kulüplerin şirketleşme yoluna giderken aynı zamanda da dernekler statüsünde faaliyetlerine devam etmeleri gerekmektedir. Spor kulüplerinin çok düşük oranlarda ortağı olduğu şirketler kurulmakta ve spor faaliyetleri bu şirketler üzerinde gözükerek devam etmektedir. Böylelikle kulüpler hem ticari işletme gibi gelir sağlayabilmekte hem de dernekler statüsünden faydalanılarak birçok vergiden muaf tutulmaktadırlar (3). Şirketleşme denilince, aslında tek bir şirketin kurulması anlaşıımamalıdır, çünkü birden çok şirketin kurulması zorunluluğu ile karşı karşıya kalınacaktır. Kurulacak şirketlerden sadece birisinin münhasıran sporcuların giderleri ve vergi muafiyetindeki gelirlerini toplamakla uğraşması gerekmektedir. Diğer yandan kurulacak ayrı bir şirket ise ticari faaliyetlere ağırlık vermeye yönelik çalışmaktadır (4). Ayrıca bazı spor kulüpleri halka arz geliri elde edebilmek amacıyla, Avrupa'da ve dünyada eşi ve örneği olmayan tamamen bilinçsiz bir şekilde şirketleşip, halka arz modeliyle Sportif A.Ş.'lerin hisselerini mali yatırımcının talebine sunmuşlardır. Spor kulübü olmaları nedeniyle taraftarın çok da temettü kaygısı içinde olmaksızın bu hisseleri alacağını düşünen spor kulüpleri, içinde bulundukları finansal durumları nedeniyle de kulübün birkaç istisna dışında hemen hemen tüm gelirlerinin Sportif A.Ş.'lere devir ve temlik olunduğu, buna karşın giderlerin kulüpte ya da Futbol A.Ş.'de bırakıldığı bir model içinde yaratılan sanal şirketler aracılığıyla iMKB'ye yöneldikleri de görülmektedir (2). Buda spor kulüplerinin şirket kurmaları veya şirketler tarafından satın alınmaları spor faaliyetlerinin çok boyutlu olarak değerlendirmeleri sonucunu doğurmaktadır (16).

5422 sayılı Kurumlar Vergisi Kanunu'nun muafiyetleri düzenleyen 4. maddesinin j bendinde ve 7. maddesinin 8. bendinde yer alan "Gençlik ve Spor Genel Müdürlüğü ile özerk spor federasyonlarına tescil edilmiş spor kulüplerinin idman ve spor faaliyetlerinde bulunan iktisadi işletmeleri ile sadece idman ve spor faaliyetlerinde bulunan anonim şirketler, Beden Terbiyesi Teşkilatı'na dahil derneklere veya kamu idare ve müesseselerine ait idman ve spor müesseseleri ile sadece idman ve spor faaliyetlerinde bulunan anonim şirketlerin" kurumlar vergisinden muaftır şeklinde belirtilmiştir. Anonim şirketler, Beden Terbiyesi Teşkilatının yayınlayacağı tüzük ve genelgeler çerçevesinde idman ve spor faaliyetlerinde bulunacaklar, bunun dışında herhangi bir faaliyette bulunmayacaklardır. Bu şartların ihlali halinde muafiyetten yararlanmaları mümkün olamayacaktır. Ancak anılan şirketlerin sporcularının formalarına aldıkları reklamlar, idman ve spor faaliyeti çerçevesinde mütalaa edilecektir. Öte yandan Beden Terbiyesi Teşkilatına dahil derneklere veya kamu idare ve müesseselerine ait idman ve spor müesseselerinin muafiyetleri aynen devam etmekte olup bunlar için bir değişiklik söz konusu değildir" hükmü çerçevesinde, spor kulüplerinin şirketleşmesi durumunda, aynen dernek çatısı altında faaliyet gösterdiklerinde olduğu gibi kurumlar vergisinden muaf olmaları sağlanmıştır. Söz konusu şirketlerin elde ettikleri temel olarak yayın gelirleri, sponsorluk ve reklam gelirleri, stadyum hasılatları, spor tesislerinde bulunan büfelerin gelirleri vergi kapsamı dışında bırakıımıştır. Dört büyük kulübün de ticari ürün satışlarını halka açtıkları şirket üzerinden değil de kurdukları ayrı şirketler üzerinden yürütmelerinin nedeni bundan dolayıdır (3).

Beşiktaş Kulübü'nün futbol şubesini bir bütün olarak kurduğu şirkete devretmesi nedeniyle, futbol şubesine ilişkin tüm giderlerin de şirket bünyesinde bulunması, özellikle futbolcu transfer giderleri, şirketin çok daha karlı çalışamamasını beraberinde getirmiştir. Diğer üç kulüpte (Trabzonspor, Galatasaray ve Fenerbahçe) ise giderler ağırlıklı olarak kulüp bünyesinde bırakıldığından ve gelirler ağırlıklı olarak söz konusu şirketlere devredildiğinden, bu şirketler oldukça karlı çalışan şirketler olmuşlardır (9). Galatasaray, Fenerbahçe ve Trabzonspor Sportif A.Ş.'lerin kullandığı modellerle halka arzdan beklenen faydalar tam olarak ortaya çıkmamaktadır. Sportif başarının önemli olduğu ve temettü dağıtımının maksimum olduğu bu modelin uygulanması uzun vadede şirketin finansal açıdan zayıflaması ile sonuçlanabilir. Şirketleşme ve halka açılma yoluna gidecek şirketlerin Beşiktaş'ın uyguladığı modeli seçmeleri kendi finansal durumlarını korumak ve yatırımcıları korumak açısından daha yararlı olacağı (6) düşünülmektedir. Çünkü Beşiktaş modeli yukarıda da belirtildiği gibi İngiltere'de uygulanan ve Avrupa ülkelerindeki spor kulüplerine teşkil eden uygulamalarla paralellik arz etmektedir.

Dünyada başarılı örneklere bakıldığında, iyi yönetilen spor kulüpleri şirketleri yeni ekonominin gereklerine uyarak medya, telekominikasyon ve internet alanında sponsorlar bularak yeni yatırımlara yönelmektedirler (4). Spor kulüplerinin şirketleşerek halka açılmalarında en başarılı örneklere, İngiltere'de rastlanmaktadır. Ülkede futbolun seyircisini artırmak için her türlü önlem alınmıştır. Daha çekişmeli maçların yapılmasını sağlamak amacıyla Süper Lig kurulmuş, stadyumlar modernleştirilmiş, büyük transferler yapılmıştır. Spor kulüpleri bu yatırımları gerçekleştirebilmek için şirketlerini halka açmışlardır (25). Bugün artık spor kulüplerinin 2012-2013 sezonundan itibaren hayata geçecek olan "UEFA Finansal Fair Play" uygulaması kapsamında bu sorunu çözümlemek zorundadırlar (2). Ayrıca şirketleşme boyutunda sadece futbol olarak değil diğer spor branşlarında da örneğin Türkiye Basketbol Federasyonu Ana Statüsü 35. maddesinde Basketbol kulüpleri ile diğer spor kulüplerinin basketbol şubelerinin ilgili kanunlarda belirtilen şekil ve esaslara göre kurulacak veya kurulmuş olan anonim şirketlere devir esaslarını ve uygulanma şartlarını belirlemektir (29) şeklinde şirketleşmenin önemi vurgulanmıştır.

Yukarıda açıklanan çalışmaların ve girişimlerin tamamı göstermektedir ki sadece büyük kulüplerin girişimlerinin diğerlerine kıyasla göreceli başarılı operasyonlar olduğu söylenebilir. Mevcut dernekler kanunu spor kulüplerinin yönetimi konusunda çok yetersiz kalmakta, çok ciddi değişiklikler gerektirmektedir (20). Sonuç olarak Türkiye'de spor kulüplerinin küreselleşen dünyada federasyonun ve kulüp yöneticilerinin gelirleriyle ayakta kalması, dünyaya ve Avrupa'ya entegre olması mümkün değildir. Bundan dolayı spor kulüplerinin profesyonel ve doğru bir şekilde şirketleşerek, halka açılma, gayrimenkul yatırım ortaklığına yönelme, yatırım şirketi kurarak yurtiçi ve yurtdışında çok önemli ticari avantajlardan 
yararlanma yoluna gitmelidir. Böylece spor kulüpleri yerli ve yabancı yatırımcılara cazip hale gelecek, kulüp yönetimini daha profesyonel bir yönetim sergilemeye yönlendirip, gelir kaynaklarını çeşitlendirecektir. Ancak spor kulüplerinin şirketleşmesi her zaman yanlış şirketleşme ve yanlış halka arz modelleriyle sermaye piyasalarına açılmak, spor kulüplerini çok ciddi finansal krizleri karşı karşıya kalabileceklerini göz ardı etmemek gerekmektedir. Çünkü spor kulüplerinde şirketleşmenin esas amacı, kurumsallaşarak ticari avantajlar elde edebilmek olmalıdır.

\section{KAYNAKÇA}

1. Akşar, T. ve Merih, K., "Futbol Ekonomisi", Literatür Yayıncılık, İstanbul, s. 470-471, 2006.

2. Akşar, T., "Sportif A.Ş.'lerden Nasıl Kurtulunur?”, http://www.dunya.com/sportif-aslerden-nasil-kurtulunur-tugrulaksar_ 109_78233_yazar.html, 2010.

3. Akyüz, M. E., "Futbol Kulüplerinin Şirketleşmesi ve Halka açılması; Avrupa Futbol Piyasasındaki Gelişmeler Çerçevesinde Beşiktaş, Fenerbahçe, Galatasaray ve Trabzonspor Örneğinin Değerlendirilmesi”, T.C.Başbakanlık Sermaye Piyasası Kurulu Aracılık Faaliyetleri Yeterlilik Etüdü, İstanbul, s. 22, 27, 2005.

4. Alptürk, E., "Futbol Endüstrisi ve Kulüplerin Şirketleşme Gerçeği", http://www.xing.com/net/cem_futbol/genel-199527/futbolendustrisi-ve-kuluplerin-sirketlesme-gercegi 20642108, 2009.

5. Aydın, A. D., "Spor Kulüplerinin Halka Açılmasının Finansal Yapıları Üzerine Etkileri”, Gazi Üniversitesi Sağılk Bilimleri Enstitüsü Doktora Tezi, Ankara, s. 30, 78, 2005.

6. Aydın, A. D., Turgut, M. ve Bayırlı, R., "Spor Kulüplerinin Halka Açılmasının Türkiye'de Uygulanan Modeller Açıından Incelenmesi", Ticaret ve Turizm Eğitim Fakültesi Dergisi, s. 1, 62- 69, 2007.

7. Balcı, V., "Avrupa Birliği ve Spor", Gazi Beden Eğitimi ve Spor Bilimleri Dergisi, VIII, 2, s. 53- 66, 2003.

8. Boon, G. and Jones, D., "Deloitte\&Touche Annual Review of Football Finance", 2004.

9. Boztaş, H., "Ülkemizde Futbol Kulüplerinin Şirketleşmesi ve Halka Arzına Genel Bir Bakış", Erişim: http://www.yaklasim.com/mevzuat/dergi/makaleler/20080912748.htm, 2008.

10. Cerrahoğlu, N. ve İmamoğlu, A. F., "Sporun Ekonomik Boyutu, Almanya Örneği", 1.Gazi Beden Eğitimi ve Spor Bilimleri Kongresi, Cilt: 2, Ankara, s. 240-247, 2000.

11. Dorukkaya, Ş., Kıratı, A. ve Ebiçoğlu, K., "Türkiye'de Futbol Kulüplerinin Şirketleşmesi, Halka Açılması, Finansmanı ve Vergileme”, Dünya Yayınları, İstanbul, s. 20-23, 1998.

12. Ekenci, G. ve İmamoğlu, A. F., Spor İşletmeciliği, 1. Baskı, Alf Ofset Matbaacılık, Ankara, s. 9, 20, 1998.

13. Ekenci, G. "Türkiye'deki Müessese Spor Kulüplerinin Kurumsal Kültürlerinin Toplam Kalite Yönetimine Uygunluğu”, Gazi Beden Eğitimi ve Spor Bilimleri Dergisi, C. 5, Sayı: 4, s. 43-54, 2000.

14. Galatasaray Spor Kulübü, Erişim: www.galatasaray.org/gs_sportif/frame.htm, 2006.

15. Galatasaray Spor Kulübü, "Galatasaray Spor Kulübü 2000 Yılı Faaliyet Raporu Kesin Hesaplar ve 2001 Yılı Bütçe Tasarısı", Erişim: www.galatasaray.org., s. 31, 2010.

16. Genç, D. A., "Spor Hukuku”, Alfa Basım Yayım Dağıtım, İstanbul, s. 46, 1998.

17. Genç, D. A., "Futbol Kulüplerinin Stratejik Yönetimi”, Bağırgan Yayınevi, Ankara, s. 27, 1999.

18. Günebakış, "Spor Kulüplerinin Şirketleşmesi”, http://www.gunebakis.com.tr/makale.php?id=1268\&archive_list=7, 2010.

19. Günışığı Gazetesi, "İşte Şirket Mağdurları", http://www.gunisigigazetesi.net, 2009.

20. Gürkan, B., "Şirketleşme Sancıları", Türkiye Futbol Federasyonu, Tam Saha Dergisi, Sayı: 26, s. 20, 22, 2006.

21. Hacıköylü, C., "Türkiye'de Profesyonel Spor Kulüplerinin ve Sporcuların Vergilendirilmesi”, Anadolu Üniversitesi Sosyal Bilimler Enstitüsü, Yüksek Lisans Tezi, Eskişehir, s. 41, 56, 2001.

22. İmamoğlu, A. F., "Fonksiyonel Açıdan Spor Yönetiminin Anlam ve Önemi”, Gazi Eğitim Fakültesi Dergisi, Cilt: 8, Sayl: I, s. 21-34, 1992.

23. İkiz, M., "Endüstriyel Futbol İçinde Türk Spor Kulüplerinin Şirketleşmeleri”, Erişim: www.supporters-direct.org, 2010.

24. İkiz, M., "Türkiye'de Spor Kulüplerinin Şirketleşmesi ve Halka Arzları", Erişim: http://www.futbolekonomi.com/Raporlar/yonetsel/ Turk\%20_Spor_\%20Kuluplerinin_\%20Sirketlesmeleri_Mete\%20ikiz_KHU_13\%20Subat\%2010.pdf, 2012.

25. Kocaoğlu N. K., "Futbol Şirketlerinin Halka Açılması", Ankara Barosu Dergisi, Yıl: 69, 2011/ 4 s. 106, 2011.

26. Sever, Ö. ve Topçular, S. "Futbol A.Ş.", http://www.haberciyes.com/haber_detay.asp?haberID=142, 2009.

27. Sultanoğlu, B., "Hisseleri Halka Arz Edilen Türk Futbol Kulüplerinin Mali Tablolarının Türkiye Muhasebe Standartları Çerçevesinde İncelenmesi", Başkent Üniversitesi Sosyal Bilimler Enstitüsü Yüksek Lisans Tezi, Ankara, s. 14-28, 2008.

28. Trabzonspor Kulübü, “Trabzonspor Sportif Yatırım ve Ticaret A.Ş.”, Halka Arz İzahnamesi, Trabzon, 2005.

29. Türkiye Basketbol Federasyonu, "Şirketleşme Yönergesi", www.tbf.org.tr. s. 2, 2010.

30. Türkiye Kurumsal Yönetim Derneği, "Kurumsal Yönetim İlkeleri Işığında Türk Futbol Kulüpleri Yönetim Rehberi, Pasifik Ofset, İstanbul, s. 36-37, 2010.

31. Türkiye Futbol Federasyonu, "5894 sayılı Türkiye Futbol Federasyonu Kuruluş ve Görevleri Hakkında Kanun", RG 26 Şubat 2011 , Sayı: 27858, Erişim: www.tff.org.tr, 2009.

32. Üçı̧ık, F., "Sporda Sorunlar ve Çözüm Önerileri", Ötüken Yayınları, İstanbul, s. 145, 1999.

33. Yıldız, S., "Profesyonel Futbol Şubeleri Bulunan Spor Kulüplerinin Mali Yapılarının Karşılaştııılması (Manchester Unıted Futbol Kulübü-Fenerbahçe Spor Kulübü Örneği)”, Marmara Üniversitesi Sağlık Bilimleri Enstitüsü Yüksek Lisans Tezi, İstanbul, s. 36, $37,2008$.

34. Wilkesmann, B., Takım Analizi, Financial Crisis in English Football Raporu (Buraimo, Simmons, Szymanski), Organizational Restructuring of German Football Clubs Raporu. 